UDC 658.6:004.738.5 (339.13)

JEL Classification: L 81, M 1, M 31

Veronika Khudolei

Doctor of Economics, Professor, Rector Academician Yuriy Bugay International Scientific and Technical University

(Kyiv, Ukraine)

Alona Natorina

PhD (Economics), Head of the International Economics Accounting and Finance Department Academician Yuriy Bugay International Scientific and Technical University

(Kyiv, Ukraine)

\title{
THE CONCATENATED PHASES OF DIGITAL BUSINESS MANAGEMENT IN DIGITAL TRANSFORMATION
}

The priority value of digital transformation at the state level, which forms the prerequisites for positive global economic and social changes in the context of bifurcations and permanent changes in the marketing environment, is determined. The digital technologies influence in various areas of enterprise activity is identified and detailed. Based on the results of the studies and a comparative analysis of scientists and economists, the relation between the key blocks of the digital business transformation that allow rapidly react to heterogeneous consumer requests in the Internet are interpreted. The architecture of digital business management in digital transformation terms is developed. It represents concatenated phases that provide increased efficiency and facilitate the rapid expansion of new market segments, as well as require for the direct implementation of relevant methodological tools.

Key words: digital transformation, blocks of digital business transformation, digital business management, concatenated phases of digital business management, online customers

\section{DOI: 10.15276/mdt.4.2.2020.4}

Statement of the problem in general form and it's connection with important scientific or practical tasks. Changes in the modern world are happening very quickly, so digital business requires a quick response and adaptation to these changes, especially in the context of digital transformation. In this case, it is important to develop an architecture for digital business management with the appropriate phases, which will be the base of relevant methodological tools usage for enterprises in response to transformation of the marketing environment, priority competitors' actions, as well as the online customers' experiences formation with taking into account global and local trends.

Analysis of the latest research and publications, which initiated the solution of this problem and on which the author relies. The theoretical aspects of digital transformation and its impact on the economy are interpreted in the works of scientists, among whom: Kaariainen J. [15], Krueger J. [11], Meek T. [12], Muller Ch. [17], Nwaiwu F. [14], Parviainen P. [15], Rachinger M. [17], Rauter R. [17], Schirgi E. [17], Schmitt B. [18], Teppola S. [15], Tihinen M. [15], Vorraber W. [17].

(C) 2020 The Authors. This is an open access article under the CC BY license (http://creativecommons.org/licenses/by/4.0) 
Also, many scientists and economists studied and analyzed the digital business soecific in the context of digital transformation - Baird N. [2], Bohm M. [7], Das S. [9], Hein A. [7], Joshi M. [9], Kathuria R. [9], Krcmar H. [7], Riasanow T. [7], Schreieck M. [7], Schwarz R. [19], Setzke D. [7], Wiesche M. [7]. Moreover, the leading companies, including those that own and maintain information and news portals, focus on research on how to conduct digital business in the digital transformation era. Among such companies: Capgemini Consulting [3], Deloitte [4], EVO.company [6], IBM [8], Kantar Ukraine [10], PWC [16].

Highlighting the previously unresolved parts of the general problem to which the article is devoted. Despite the large number of theoretical and applied works regarding doing business in the context of digital transformation, nowadays there is no common concept and unified guides for digital business management. This emphasizes the importance and significance of the research topic chosen by the authors.

Formulation of the purpose of the article (statement of the problem). The purpose of the article is to develop the architecture of digital business management with concatenated phases in the digital transformation context considering the importance and impact of digital technology in various areas of enterprise activity at the national level.

Statement of the main material of the research with full justification of the scientific results obtained. The flows of physical goods and finances were the hallmarks of the world economy of the last century, however, now their scale is decreasing. This is because today globalization processes are determined by the flows of data, information and communication technologies and digital technologies that permanently transform the economy. Given the above, it is formulated the dominants of the country's digital economy in the context of globalization, the implementation of which at the state level will ensure the continuous progressive business development in different market segments:

1) to promote the social, economic development of the country by implementing an integrated approach to digitalization based on the "open data" principles;

2) to stimulate the emergence of digital innovation in the economy;

3 ) to convergent of relevant information and communication technologies in order to create new opportunities for improving online platforms;

4) to ensure the growth of customer confidence during their online platforms usage, which will be one of the key tasks for the sustainable development of the digital economy;

5) to guarantee the digital security necessary for the economic and social prosperity of the country;

6) to promote the emergence of new online markets by stakeholders and, as a result, to increase the number of jobs in the IT sector, given the rapid development of digital technologies;

7) to comply with the fundamental principles for providing the public access to the Internet (openness, accessibility) and, at the same time, to ensure the protection of confidentiality and intellectual property customers rights online;

8) to implement a policy to increase public confidence in the Internet;

9) to train staff and improve their qualifications in the IT sector, taking into account the intensification of digital technologies;

10) to promote the training of highly qualified staff by providing them with the competencies necessary to attract and fully participate in the digital transformation of the economy based on the results of research and analysis of mechanisms for working with digital technologies;

11) to develop strategies for confidentiality and data protection at the state level, taking into account the needs of society when using digital technologies. 
Regarding the last mentioned dominant, it should be noted that due to the intensive use of information and communication technologies, the business faces significant risks in the field of digital security and privacy; in particular, it needs to implement and / or improve risk management methods. Many countries are implementing national digital security strategies, but only a few have national confidentiality. Meanwhile, privacy risks increase customer concerns about online fraud, reimbursement mechanisms and the quality of online products and services, can limit their trust in a certain way and significantly reduce online trading volumes. Therefore, the policy of protecting customers' rights on the Internet should be focused on increasing trust and leveling the risks associated with any online activity.

The digital transformation of the business in order to follow current market trends and ensure stable operation provides a number of advantages, namely, wide target audience and the maximum possible level of impact on it with using relevant, low-cost marketing communications. Only enterprises that rationally carry out digital transformation to monitor inquiries, customer needs and forecast the expectations and preferences of online customers occupy leading positions in the market, significantly ahead of priority competitors.

Digital technologies significantly change customer behavior online and offline, their individual attitude to various areas of business activity. They also necessitate the reconfiguration of the current construct of the business model, which is applied by businesses in practice, and, as a result, has a direct impact on various sectors of the economy as a stimulator of new business processes and economic systems. Based on the analysis of studies $[1 ; 3-6 ; 8$; $10 ; 16]$, the influence of digital technologies in different areas of business activity are determined.

Area 1. Banking services. Digital technologies allow businesses to create high-quality and customer-oriented products and services, modify the system of interaction with customers, adapt business models, modernize electronic banking processes, implement new approaches to staff management, which are necessary for the successful operation of enterprises in the banking services market. Given the above, the key areas of sustainable business operations in this market is to ensure the safety of customers in the provision of services, the development and need for information support of online payment platforms.

Area 2. Healthcare. The use of digital technologies in the healthcare area allows expanding the range of opportunities from digitalization of traditional systems to the formation of a network for the services targeted provision at specific customers according to a personalized approach to services.

Area 3. High technology. Today, the competitive advantages of a business are largely determined by information and communication support. The synthesis of digital and high technologies allows the business to achieve an unprecedented level of understanding and satisfaction of market needs, to implement the correct monitoring and control system for current activities. Digital technologies contribute to the timely response to existing demand and the development of new areas of business activity, including finding and reaching new market niches.

Area 4. Production. Smart production, as well as synchronized digitized business processes are the basis of the digital transformation of the industry in a changing marketing environment. This implies the rapid achievement of a strategic goal, and is a prerequisite for revenue growth and cost reduction by maximizing customer satisfaction.

Area 5. Retail. The large number of devices and gadgets led to radical change imperatives of business and made it necessary to digitize their activities. That is why retailers occupy the positions of market leaders in modern conditions, they are integrated omnichannel structures focused on digital ways of interacting with customers. The compilation of personalized services of interactive digital goods and services provides a more integrated 
approach to customer relationship management, and also provides an opportunity to predict the possible reaction of customers to certain actions and changes of the business.

Area 6. Transport services. The use of digital technologies with the effective innovative strategy realization allows businesses in the transport services (area 6) to optimize the execution of online business operations, which is a guarantee of their productive activities in the future.

Based on the results of research and analysis of the work of scientists and economists $[2 ; 4 ; 6-7 ; 14-15 ; 16-17]$, the relation between the key blocks of digital business transformation that allows quickly response to requests in the Internet is explicated and interpreted.

1. General data administration, their consistency and quality, as well as effective business models allow to accumulate and process large volumes of data.

2. Advanced applied statistical methods and algorithms in combination with artificial intelligence contribute to the development of alternative solutions based on analytics.

3. The upgraded data environment, including data architecture and underlying systems, becomes flexible through virtualization and the use of cloud technologies.

4. Relevant infrastructure provides a stable and coordinated interaction of online customers and managers simultaneously on different devices and gadgets.

5. Online tools and applications provide online customers and managers the ability to monitor and analyze the totality of their sequential online actions.

6. Partnership with entities in the online environment enhances the capabilities of digital business and accelerates the expansion of the necessary market share.

7. Staff that owns digital knowledge, skills, and sufficient experience for stable and productive work, including the correct organization of monitoring and comparative analysis of the priority competitors' activities.

8. The flexible organizational culture encourages mutually beneficial collaboration with stakeholders to achieve a common goal.

The management of digital business is becoming prevailing in accordance with current online environment trends and taking into account the specifics of business processes digitalization. The architectural representation of digital business management in the digital transformation is shown in Figure 1.

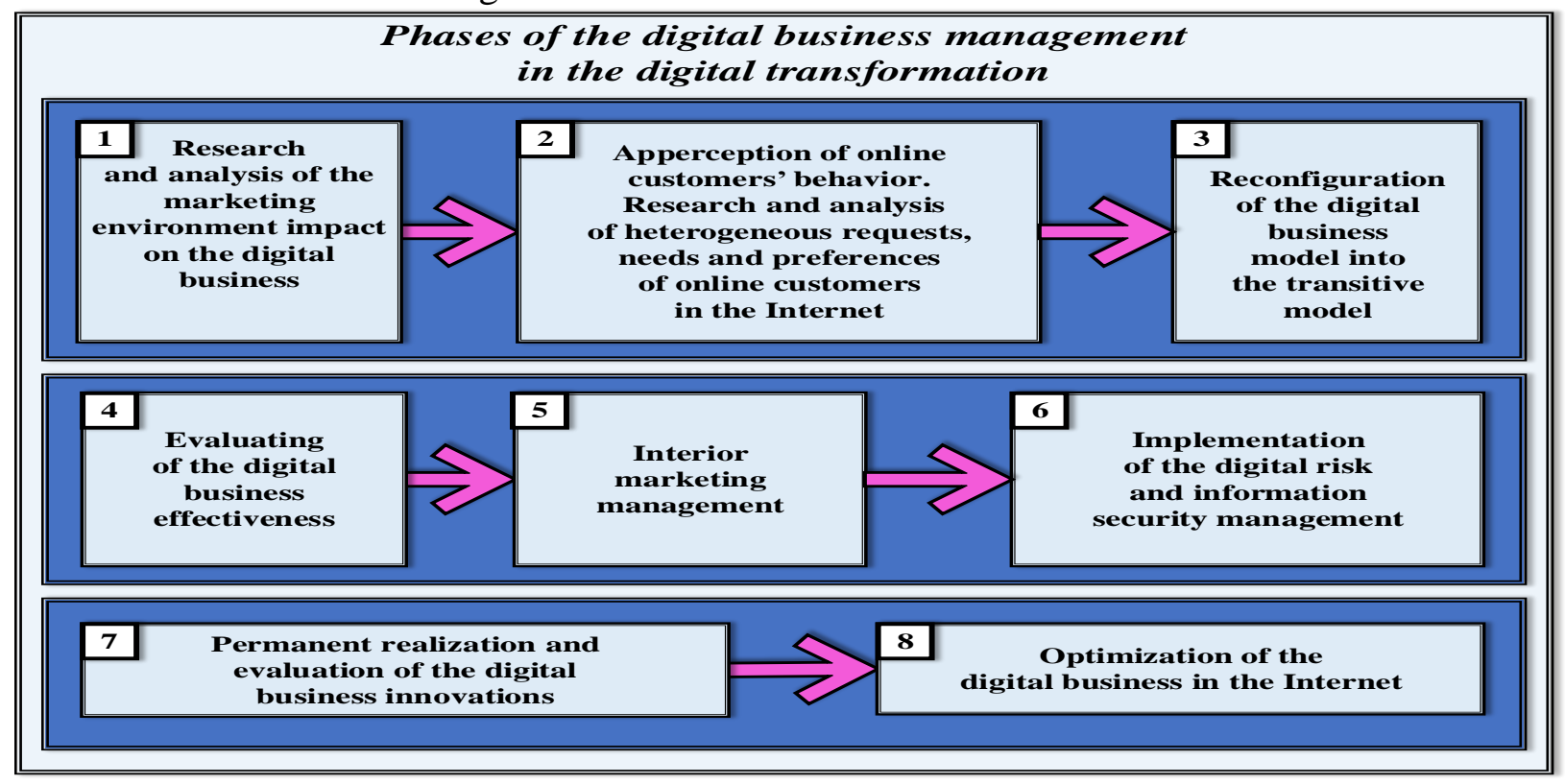

Figure 1 - The concatenated phases of digital business management in the digital transformation 
Source: created by the authors

According to the Figure 1, the digital business management in the digital transformation is a concatenation of 8 phases that:

1) provide for increasing the efficiency of businesses in the variability of heterogeneous requests, the needs and preferences of online customers and an aggressive competitive background and, moreover, in bifurcation periods;

2) contribute to the rapid expansion of new market segments based on the relevant methodological tools usage.

Research and analysis of the marketing environment influence on the digital business is an integral component of digital transformation, because the formation of the business vision and justification, selection and adjustment of relevant market strategies at various hierarchical levels takes into account the influence of macro and microenvironment factors.

The structure of consumption and perception of goods / services by online customers is radically changing in the digital transformation context. Considering this, for the rational online business management and the identification of promising business areas, it is necessary to systematically verify the actions of online customers. Online customers regularly increase the requirements for goods / services and need instant satisfaction of their own preferences due to the positive experience in the context of the progressive development of information and communication technologies.

Understanding of the online customer behavior is the most important postulate of digital business expansion with simultaneous adherence to the trends in the digital transformation period. Taking into account the results of research $[1-2 ; 4-9 ; 10-12 ; 18-19]$, the distinctive features of the online customer behavior in the digital transformation are determined (Figure 2).

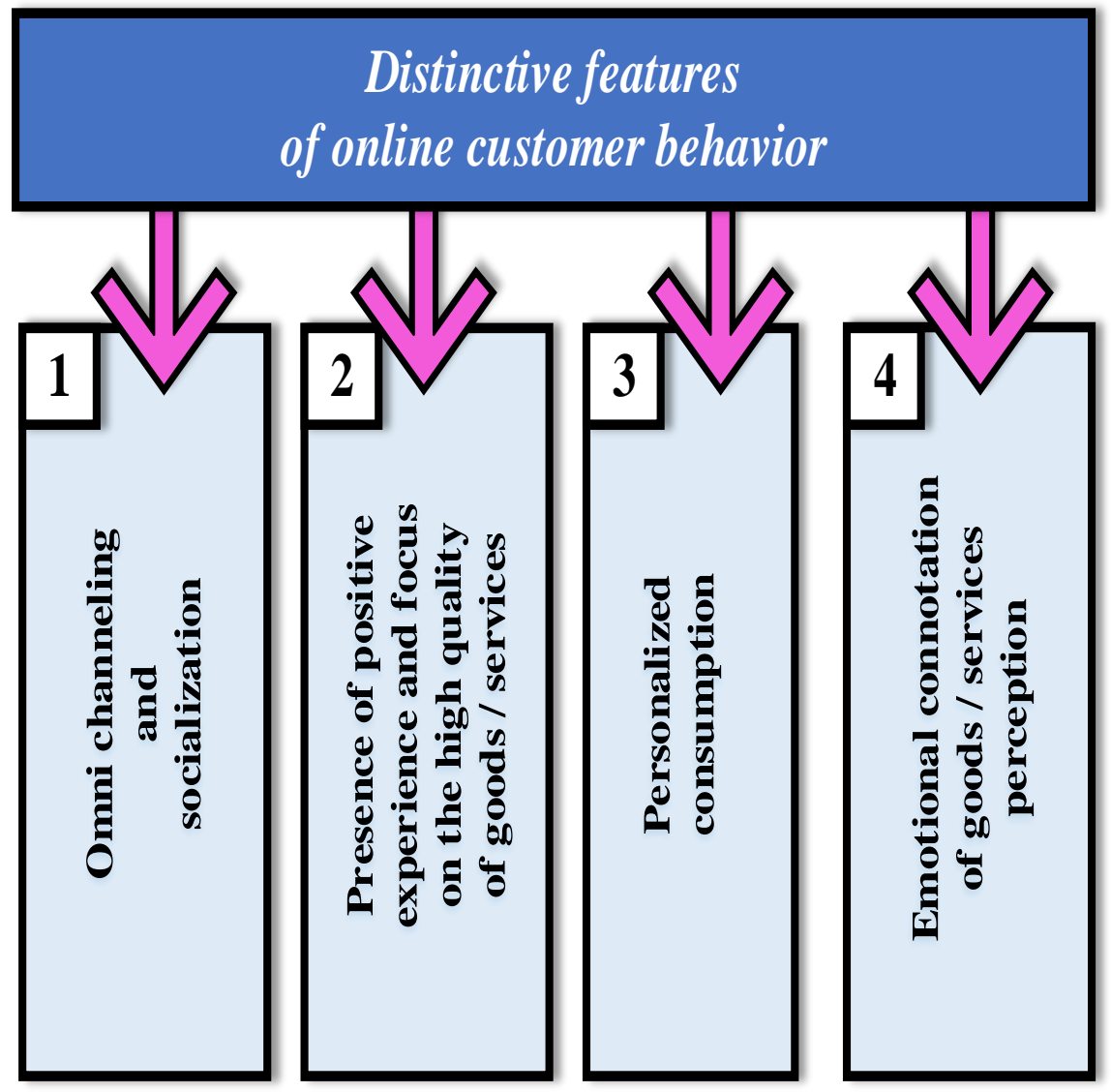

Figure 2 - The distinctive features of the online customer behavior 
Source: created by the authors

Below in the text is given an interpretation of the distinctive features of the online customer behavior, which are presented in Figure 2.

1. Omni channeling and socialization. Changes in customer behavior are generally reflected in the digitized channel and socialized online shops. First, the penetration of the Internet and the massive use of devices and gadgets make easy to collect data for enterprises and online customers. This allows to get complex information about the goods that interest online customers, because, as noted in [6;11;18-19], online customers spend in the Internet $90 \%$ of their time to search for information / reviews and comments about products in an omnichannel online environment. Secondly, enterprises engaged in online activities have huge potential in social networks. United online customers tend to have a deep sense of identity in values and aesthetics, as well as similarities in the behavior and intentions of the acquisition. In addition, in such a stable community, created consciously or subconsciously, the interaction between online customers goes on a closed cycle. This contributes to the modification of the online content about aspects of the digital business development and positively affects its market reputation.

2. Presence of positive experience and focus on the high quality of goods / services. In the context of digital transformation, the concept of consumption is gradually transforming from a price-oriented to a quality-oriented one - beyond the traditional meaning of physical or monetary value. The range of goods / services in the Internet is constantly expanding, so the enterprise should study the components affecting the value market offers formation. So, B. Schmitt in his work [18] identified such five components:

1) senses (including the five human senses - vision, sound, smell, taste and touch);

2) feelings (positive emotional experiences);

3) thinking (appeals to intelligence and creative thinking);

4) actions (cause changes in behavior and lifestyle);

5) relation (search for belonging and meaning).

The formation of a value-based market offer for online customers takes into account these important components for digital business development in the online environment. The attractiveness of the market offer for the online customers is the combination of the sensitive value and their positive experience in previous using of goods / services.

3. Personalized consumption.

4. Emotional connotation of goods / services perception is the additional determining factor. In general, online customers prefer to purchase personalized and niche goods / services and at the same time seek recognition by subcultural communities. Online customers tend to share impressions and experiences about online sales in social networks.

Investigation of heterogeneous requests, needs and preferences of online customers in the Internet as part of the effective management of digital business provides:

1. Market research for a detailed study of customers' preferences in specific geographical regions (market segments), as well as monitoring and analysis of social networks in order to identify the degree of online customers' satisfaction with certain goods / services.

2. Strengthening analytical capabilities for a deeper understanding of online customers.

3. Systematic collection of marketing information about online customers and the formation of a register of data about them.

4. Tracking of the degree of online customers' awareness in the online environment.

5. Creation of business accounts and profiles in the Internet to advise and increase the loyalty of regular online customers, in particular, to quickly respond to complaints.

6. Regular surveys of online customers in order to track their actions and reactions in relation to certain goods / services.

V. Khudolei, A. Natorina. The Concatenated Phases of Digital Business Management in Digital Transformation 
7. Mobile applications Usage to collect detailed information about requests, needs and preferences of online customers, understanding the specific of their experience transformation, as well as implementing analytical planning. Mobile applications provide access to online customers account information. The development of customized mobile applications can improve the quality of online customer service. For example, smartphone applications related to the personal customer profile, allow enterprises to integrate data into SMS messages with attachments on social networks. Applications with geolocation and augmented reality can help customers find places of sales and search for special assortment offers, as well as receive systematically receive push notifications.

8. Ensuring the personalization of online sales.

9. Local marketing and integration of offline and online services.

10. Optimization of business processes through the use of the online plug-in with the ability to download the latest list of online customer orders and an acceptable method of goods delivery, allows enterprises in the Internet to collect the necessary statistics and, in turn, simplifies the process of ordering goods for online customers, allowing them to pay more time to choose other products.

11. The implementation of integrated multi-channel communication activities using IT innovation in relations with online customers.

The essence and mechanism of reconfiguration of the traditional business digital business model into the transitive is given in the article by Natorina A. [13].

Implementation of interior marketing management as part of digital business management in the digital transformation needs:

A. Automation of operational business processes.

In order to develop more efficient, scalable operational business processes, enterprises should automate data to make rational decisions. Thus, ERP will provide significant efficiency and quality improvements in the main transactional, financial business processes and supply chains, and will create a central platform for the main business processes. Also, automation will allow enterprises to orient staff towards the rapid implementation of strategic tasks. Enterprises will be able to centralize staff functions, save some money and, at the same time, focus on improving staff managerial skills and increasing their level of competence. Automation of business processes, the components of which are research and IT development, also will allow enterprises to concentrate on innovation, as well as create data flows that can be used in further attempts to collect and synthesize marketing information.

B. Virtualization of individual staff work.

It means he development of mobile applications for devices and gadgets for the general staff work, expert surveys and consulting real-time video conferences conduction, access to a single global registry of online customers. It should be noted that the basis for digital business transformations creates staff that communicate with online customers in different geolocations. Enterprises have opportunities to support two-way communication scalable due to changing the limited one-way vertical communication with online customers in certain marketing communication channels - vertical and horizontal.

C. Transactional performance systems.

Guaranteeing the transparency performance systems is a key moment in the digital business. Due to that fact, managers are more informed about the current operating and economic situation, and, as a result, take reasonable administrative decisions for digital business. So the transactional performance systems will provide an opportunity to better understand the needs, requirements and preferences of online customers when they choose goods / services. 
Analysis of the dynamics of the relevant metrics for evaluating of the digital business management contributes to better business processes diagnostics and improvement. Therefore, the transactional productivity systems could positively impact strategic planning and enable enterprises to quickly identify existing issues and problems.

It can be stated that the effective digital business management in the context of digital transformation requires reconfiguration of the business model into a transitive one, as part of a clear vision and the implementation of a competitive market strategy in the online space, taking into account the prevailing digital trends.

Conclusions from this research and prospects for further developments in this area. The priority value of digital transformation at the state level, which forms the prerequisites for positive global economic and social changes in the context of bifurcations and permanent changes in the marketing environment, is determined. The digital technologies influence in various areas of enterprise activity is identified and detailed. Based on the results of a study and a comparative analysis of scientists and economists works, the relation between the key blocks of the digital business transformation are interpreted. It allows rapidly react to heterogeneous consumer requests in the Internet. The architecture of digital business management in digital transformation terms is developed. It represents eight concatenated phases. The distinctive features of the online customer behavior are interpreted. Investigation of heterogeneous requests, needs and preferences of online customers in the Internet as part of the effective management of digital business are justified and analyzed. It is proved that the implementation of interior marketing management insures the operational business processes transformation and can be considered as a trigger for making correct decisions. The components of interior marketing management are presented. Moreover, the authors focus on the fact that the effective digital business management requires reconfiguration of the business model in a transitive one as part of the implementation of a competitive strategy that takes into account digital trends.

1. All Retail. (2020) Available at: http://allretail.ua/ (accessed 15 May 2020).

2. Baird, N. (2018) What digital transformation actually means for retail. Forbes. Available at: https://www.forbes.com/sites/nikkibaird/2018/03/13/what-digital-transformation-actually-means-forretail/\#7e24e8eb7038 (accessed 20 May 2020).

3. Capgemini Consulting. (2017) Digital transformation: a roadmap for billion-dollar organizations: MIT Center for Digital Business, Capgemini Consulting. Available at: https://www.capgemini.com/wpcontent/uploads/2017/07/Digital_Transformation_A_Road-Map_for_Billion-Dollar_Organizations. pdf (accessed 23 May 2020).

4. Deloitte. (2019) Global retail, wholesale \& distribution. Available at: https://www2.deloitte.com/global/en/pages/consumer-business/topics/retail-wholesaledistribution.html?icid=top_retail-wholesale-distribution (accessed accessed 1 June 2020).

5. Ecommerce News Europe. (2020) Available at: https://ecommercenews.eu/ (accessed 1 June 2020). 6. EVO.company. (2019) Available at: https://evo.company/ua/ (accessed 23 May 2020).

7. Hein, A., Schreieck, M., Riasanow, T., Setzke, D., Wiesche, M., Bohm, M. \& Krcmar, H. (2019) Digital platform ecosystems. Electronic Markets. DOI: https://doi.org/10.1007/s12525-019-00377-4 (accessed 12 May 2020).

8. IBM (2019). Available at: https://www.ibm.com/ (accessed 1 June 2020).

9. Joshi, M., Kathuria, R. \& Das, S. (2018) Corporate entrepreneurship in the digital era: the cascading effect through operations. The Journal of Entrepreneurship, vol.28(1), pp.4-34. DOI: https://doi.org/10.1177/0971355718810554 (accessed 27 May 2020).

10. Kantar Ukraine. (2020) Available at: https://tns-ua.com/ (accessed 19 May 2020).

V. Khudolei, A. Natorina. The Concatenated Phases of Digital Business Management in Digital Transformation 
11. Krueger, J. (2015) Omnichannel shoppers: An emerging retail reality. Think with Google. Available at: https://www.thinkwithgoogle.com/marketing-resources/omnichannel/omni-channel-shoppers-anemerging-retail-reality/ (accessed 20 December 2017).

12. Meek, T. (2018) Big Data in retail: how to win with predictive analytics. Forbes. Available at: https://www.forbes.com/sites/netapp/2015/02/18/big-data-in-retail/ (accessed 11 September 2018).

13. Natorina, A. O. (2019) Tranzytyvna biznes-model tsyfrovoho biznesu: sutnist ta mekhanizm rekonfihuruvannia [Transitive business model of digital business: the nature and mechanism of reconfiguration]. Visnyk ahrarnoi nauky Prychornomoria [Ukrainian Black Sea region agrarian science], vol. 3 (103), pp. 36-43. Available at: https://visnyk.mnau.edu.ua/statti/2019/n103/ n103v3r2019natorina.pdf (in Ukrainian) (accessed 10 May 2020).

14. Nwaiwu, F. (2018) Review and comparison of conceptual frameworks on digital business transformation. Journal of Competitiveness, vol. $10 \quad$ (3), pp. 86-100. DOI: https://doi.org/10.7441/joc.2018.03.06 (accessed 1 June 2020).

15. Parviainen, P., Tihinen, M., Kaariainen, J. \& Teppola, S. (2017) Tackling the digitalization challenge: how to benefit from digitalization in practice. International Journal of Information Systems and Project Management, vol. 5, no. 1, pp.63-77. DOI: https://doi.org/10.12821/ijispm050104 (accessed 23 May 2020).

16. PWC. (2020) Available at: https://www.pwc.com/ (accessed 18 May 2020).

17. Rachinger, M., Rauter, R., Muller, Ch., Vorraber, W. \& Schirgi, E. (2019) Digitalization and its influence on business model innovation. Journal of Manufacturing Technology Management, vol. 30, no. 8, pp. 1143-1160. DOI: https://doi.org/10.1108/JMTM-01-2018-0020 (accessed 10 May 2020).

18. Schmitt, B. (2011) Experience Marketing: Concepts, Frameworks and Consumer Insights. Foundations and Trends in Marketing, vol. 5, no. 2, pp. 55-112. DOI: http://dx.doi.org/10.1561/1700000027 (accessed 12 May 2020).

19. Schwarz, R. (2016) Special CRM. The customer in the center of digital transformation. Detecon Management Report, vol. 1, 86 p. Available at: https://docplayer.net/19794580-Detecon-managementreport.html (accessed 18 May 2020).

Худолей Вероніка Юрї̈вна, доктор економічних наук, професор, ректор, Міжнародний науково-технічний університет імені академіка Юрія Бугая (Київ, Украӥна).

Наторіна Альона Олександрівна, кандидат економічних наук, завідувач кафедри міжнародної економіки, обліку та фінансів, Міжнародний науково-технічний університет імені академіка Юрія Бугая (Київ, Украӥна). трансформації.

Конкатенативні фазиси управління цифровим бізнесом в умовах цифрової

Детерміновано пріоритетне значення цифрової трансформачії на державному рівні, щео формує передумови позитивних глобальних економічних $і$ соиіальних зрушень у контексті біфуркацій та перманентних змін маркетингового середовища. Ідентифіковано та деталізовано вплив ичифрових технологій у розрізі різних сфер діяльності підприємств. Грунтуючись на результатах дослідження та компаративного аналізу робіт науковиів й економістів, інтерпретовано реляиію між ключовими блоками трансформації циифрового бізнесу, що дозволяють своєчасно реагувати на гетерогенні запити споживачів в Інтернет. Розроблено архітектуру управління цифровим бізнесом в умовах иифрової трансформації, що репрезентує конкатенативні фазиси, які забезпечують підвищення ефективності діяльності та сприяють швидкій експансії нових ринкових сегментів, а також потребують безпосередню імплементацію релевантного методичного інструментарію.

Ключові слова: цифрова трансформація, блоки трансформації цифрового бізнесу, управління цифровим бізнесом, конкатенативні фазиси управління цифровим бізнесом, онлайнпокупці.

Received to the editor June 12, 2020 